\title{
Spatial pattern of genetic and morphological diversity in the direct developer Acanthina monodon (Gastropoda: Mollusca)
}

\author{
R. Sánchez ${ }^{1}$, R. D. Sepúlveda ${ }^{1}$, A. Brante ${ }^{2}$, L. Cárdenas ${ }^{1, *}$ \\ ${ }^{1}$ Instituto de Ecología y Evolución, Facultad de Ciencias, Universidad Austral de Chile, Casilla 567, Valdivia, Chile \\ ${ }^{2}$ Departamento de Ecología, Facultad de Ciencias, Universidad Católica de la Santísima Concepción, Casilla 297, \\ Concepción, Chile
}

\begin{abstract}
Three biogeographic areas have been recognized along the Chilean coast, with biogeographic breaks located at 30 and $42^{\circ} \mathrm{S}$ allowing us to test the concordance between biogeographic patterns and spatial patterns of genetic and morphological diversity in marine species. We examined the marine gastropod Acanthina monodon, whose range spans the 2 major biogeographic breaks detected in the South-Eastern Pacific (SEP) coast. This species exhibits high variability in the morphology of its shell and has a direct development cycle. Based on the analysis of mitochondrial sequences of 258 individuals from 9 locations in the 3 biogeographic areas, we found 3 clades with contrasting levels of genetic diversity and with spatial population genetic structure. A perfect match between biogeography and pylogeography was observed only at the $30^{\circ} \mathrm{S}$ break. In contrast, we did not find a clear genetic break in concordance with the $42^{\circ} \mathrm{S}$ phylogeographic break, although haplotype distribution suggested a second phylogeographic boundary located between 45 and $53^{\circ} \mathrm{S}$. Only one haplotype was observed in the most southerly location, which may be explained by the historical influence of glaciations. A break in shell morphology was evidenced only at around 40 to $46^{\circ} \mathrm{S}$, with a group characterized by thinner shells and longer spires compared to the northern group. Our results supported the concordance hypothesis and indicated that the influence of life cycle strategy, habitat discontinuity and historical processes may determine the phylogeographical and shell morphology spatial pattern of A. monodon. In contrast to previous studies, our genetic analysis showed the presence of a single Acanthina species along the SEP coast.
\end{abstract}

KEY WORDS: Southeastern Pacific Coast $\cdot$ Marine snail $\cdot$ Phylogeography $\cdot$ Morphology $\cdot$ mtDNA Resale or republication not permitted without written consent of the publisher

\section{INTRODUCTION}

Biogeographic breaks are areas where the range limits of a large number of species coincide (Cox \& Moore 2000). At the intraspecific level these areas are characterised by changes in abundance, population, and recruitment dynamics (e.g. Broitman et al. 2001, Rivadeneira et al. 2002). Also, changes in phenotypic traits are coincident with biogeographic breaks (e.g. Sanford et al. 2003, Ragionieri et al. 2009). At the genetic level, concordance between biogeographic and phylogeographic boundaries has been reported (Burton 1998). The concordance between biogeographic breaks and phenotypic and genetic breaks suggests that the same factors (physical and biological) that define species distributions are expected to demarcate boundaries within species (Avise et al. 1987). In the marine realm, few studies have evaluated how species with different life histories and dispersal abilities respond to biogeographic breaks at the phenotypic and genetic level. Moreover, most studies have been carried out in the Northern Hemisphere and few along Southern Hemisphere coasts, where physical characteristics, geolog- 
ical histories, and evolutionary context are clearly different.

The South-Eastern Pacific (SEP) coast presents 2 major biogeographical breaks defining 3 main biogeographical areas (Camus 2001, Thiel et al. 2007): the Peruvian Province (PP), the Intermediate Area (IA), and the Magellan Province (MP). The northern break is around $30^{\circ} \mathrm{S}$ and corresponds to the southern boundary of the PP, characterized by an important shift in the diversity, abundance, and recruitment of several intertidal marine invertebrate species (Broitman et al. 2001, Rivadeneira et al. 2002). This break correlates with changes in the patterns of sea surface temperatures and currents (Broitman et al. 2001, Hormazabal et al. 2004) and an abrupt narrowing of the continental shelf (Strub et al. 1998). Also, north of this break the coast is strongly influenced by natural cycles such as El Niño/Southern Oscillation (McPhaden 1999) and the Pacific Decadal Oscillation (Chavez et al. 2003). The southern break is located at around $42^{\circ} \mathrm{S}$ and has been recognized as a major biogeographical discontinuity (Camus 2001). At this latitude, the divergence of the main oceanic currents (Humboldt and Cape Horn current systems) occurs, coinciding with the northern boundary of the MP (Valdovinos et al. 2003). This area is comprised of a complex system of islands, fjords and channels and the southernmost portion was covered by an extensive ice sheet during the last glacial maximum which extended westward to the edge of continental shelf (Hulton et al. 2002). Thus, the SEP coast offers a unique opportunity to test for the influence of oceanography, biogeography and historical events on the spatial distribution of genetic and morphological diversity in marine species.

Although the SEP coast has enormous potential for testing phylogeographic hypotheses in the sea, to date only a few studies have been published, mainly focused on population genetics. These few studies suggest that the existence of concordance between biogeographic and genetic breaks depends on the dispersal potential of the species (Cárdenas et al. 2009, Tellier et al. 2009, Zakas et al. 2009, Fraser et al. 2010, Macaya \& Zuccarello 2010). Although these studies have increased our knowledge of the genetic structure of marine species along the SEP coast, the study of principally the $30^{\circ} \mathrm{S}$ biogeographic break, and the few species considered, says very little about the past and present forces that shape intraspecific variation (Kelly \& Eernisse 2007). Moreover, all the marine species studied to data have an intermediate dispersal stage (larva or spores), so no inferences may be made with respect to the importance of life history strategies for the understanding of population genetic diversity along this coast.

Many morphological traits are closely related to the fitness of the individual and these traits are expected to vary in response to environmental changes. The information compiled from studies in the Northern Hemisphere show that shell morphology varies according to wave exposure level, with thicker shells and wider opercula in individuals exposed to high wave action (Johannesson \& Johannesson 1996, Carballo et al. 2001, Conde-Padín et al. 2007). Also, predation strength positively correlates with the thickness of the shell (Trussell \& Smith 2000). Although important changes in physical and biological conditions have been reported across the 2 main biogeographic breaks of the SEP coast, there are no studies evaluating intraspecific diversity of morphological traits at a large spatial scale in marine species, making it impossible to explore more general patterns. Thus there is an urgent need for more comprehensive studies in order to enhance our understanding of the distribution of biodiversity in this region.

The marine gastropod Acanthina monodon is a muricid species endemic to the SEP coast, inhabiting intertidal rocky shores and the shallow subtidal from 28 to $55^{\circ} \mathrm{S}$ and thus spanning the 3 biogeographic areas of the SEP coast (Gallardo 1979, Valdovinos 1999). Acanthina monodon is dioecious with internal fertilization; females enclose their offspring in capsules attached to hard substrata. This species has direct development, which means that juveniles of approx. 0.82 to $1.3 \mathrm{~mm}$ hatch from the capsules after 60 to $80 \mathrm{~d}$ of intracapsular development (Gallardo 1979). Thus, in absence of a pelagic larva, the potential for dispersal in A. monodon should be very low and consequently a high level of population genetic structure could be expected. Also, A. monodon shows great variation in the shape, colour and thickness of the shell. In fact, some authors using morphological traits have recognized at least 2 species inhabiting the SEP coast (DeVries 2003). In contrast, other authors suggested that there is only 1 species with a high level of shell plasticity in response to environmental variability. Thus, we can hypothesize that if the high variability in shell morphology is an attribute of only one species (A. monodon) along the SEP coast and is associated with macroscale environmental variation, then the high morphological variability of $A$. monodon may be maintained at the regional level in congruence with the present biogeographic pattern of the area. Using cytochrome oxidase I (COI) gene sequence variation in association with a morphological analysis, we studied a total of 258 individuals of $A$. monodon to test for (1) the level of the spatial population genetic structure and (2) the existence of concordance between genetic, morphological, and biogeographical breaks along the SEP coast in a direct developer marine invertebrate species. 


\section{MATERIALS AND METHODS}

Sampling. Specimens of Acanthina monodon were collected along the SEP coast between 28 and $53^{\circ} \mathrm{S}$ covering its entire geographic range and more than $2700 \mathrm{~km}$ of coastline. At least 2 locations were sampled (see Table 1) in each of the 3 biogeographical areas. Individuals were collected during low tide from the intertidal rocky shore between October 2008 and April 2009 (one reproductive season). Body sizes of the snails ranged from 20 to $60 \mathrm{~mm}$ in total length. Immediately after collection, a piece of tissue of approx. $1 \mathrm{~cm}^{2}$ was obtained from the edge of the foot muscle of each individual and stored in $95 \%$ ethanol for genetic analyses. The shells were then cleaned and stored in the laboratory for morphometric analyses.

Extraction, amplification and sequencing of DNA. Total DNA was extracted using the phenol:chloroform method (Sambrook et al. 1989) and quantified using a spectrophotometer (Nanodrop). We used the universal primers designed by Folmer et al. (1994) to amplify the mitochondrial COI gene. PCR amplifications were performed in a $25 \mu \mathrm{l}$ reaction volume containing $0.2 \mathrm{U}$ of Taq DNA polymerase (Fermentas), $1 \times$ reaction buffer, $0.2 \mathrm{mM}$ dNTPs, $3.0 \mathrm{mM} \mathrm{MgCl} 2,1 \times \mathrm{BSA}_{2}, 10 \mathrm{pmol}$ of each primer and approximately $100 \mathrm{ng}$ of template DNA. The PCR began with an initial denaturation $\left(5 \mathrm{~min}\right.$ at $\left.95^{\circ} \mathrm{C}\right)$ followed by 40 cycles of $95^{\circ} \mathrm{C}(45 \mathrm{~s})$, $50^{\circ} \mathrm{C}(45 \mathrm{~s})$, and $72^{\circ} \mathrm{C}(1 \mathrm{~min})$ and a final extension at $72^{\circ} \mathrm{C}$ (10 min). PCR products were purified with the PCR E.Z.N.A. Cycle Pure Kit (Omega Bio-Tek) and automatically sequenced in Macrogen. To minimize sequencing errors, both strands were sequenced from the COI for each individual sample. Sequences were edited using the Proseq v3.0 software (Filatov 2002) and aligned in Clustal X 2.0.9 (Thompson et al. 1997).

Genetic analysis. Standard genetic diversity indices, such as number of mitochondrial haplotypes $\left(N_{\text {hap }}\right)$, number of polymorphic sites $(S)$, genetic diversity represented by the expected heterozygosity $\left(H_{\mathrm{e}}\right)$, nucleotide diversity $\left(\pi_{1}\right)$ and mean number of pairwise differences $\left(\pi_{2}\right)$, were estimated for each location and biogeographic area using the Arlequin 3.11 software (Excoffier et al. 2005). To compare $H_{\mathrm{e}}$ between biogeographic areas, a Kruskal-Wallis test was performed. In order to explore latitudinal patterns in genetic diversity, a Spearman correlation test was carried out. Both analyses were performed with the software Statistica 7.0 (StatSoft).

The population structure of Acanthina monodon was studied by calculating pairwise genetic differentiation $F_{\mathrm{ST}}$ between locations. The significance of pairwise $F_{\mathrm{ST}}$ was based on 10000 permutations as implemented in Arlequin (Excoffier et al. 1992). The regional pattern of genetic structure was investigated first, performing a traditional analysis of molecular variance (AMOVA) analysis using the biogeographic classification of the SEP coast as geographical subdivisions (Camus 2001). Secondly, we applied a spatial analysis of molecular variance (SAMOVA) test (Dupanloup et al. 2002) to explore the possibility of alternative patterns of population subdivision (e.g. genetic breaks). Thus, the genetic differentiation was investigated using a hierarchical analysis of the genetic variance by partitioning an estimator of $F_{\mathrm{ST}}$ into 2 components, $F_{\mathrm{SC}}$ and $F_{\mathrm{CT}}$, indicating the genetic differentiation of samples within and between biogeographic areas, respectively. An isolationby-distance model was used to test the hypothesis of step-by-step dispersal of A. monodon along the SEP coast, using a Mantel test implemented in Arlequin. To represent the spatial distribution of haplotypes we constructed a haplotype network using the Median Joining algorithm, implemented in the Network 4.5.1 software (Bandelt et al. 1999). We applied a maximum parsimony algorithm to simplify the complex branching pattern and to represent the most parsimonious intraspecific phylogenies (Polzin \& Daneshmand 2003).

Demographic and/or selective history at mtDNA locus was examined by calculating the Tajima's $D$ (Tajima 1989) and Fu's $F_{S}$ indices (Fu 1997) in Arlequin. For further examination of the historical demographic changes in Acanthina monodon we constructed a mismatch distribution and compared it to the Poisson expectation for both constant and varying population sizes (Slatkin \& Hudson 1991). The mismatch distribution analysis was performed following the results of the population structure analysis.

Morphological analysis. A geometric morphometric analysis was conducted to determinate if the morphological variation observed in Acanthina monodon throughout its distributional range was related to the biogeographical pattern of the SEP coast. We used a geometrical analysis model using morphological coordinates (or landmarks) as the raw data. This method studies the covariation between shape variables taking into account the superposition of 2 coordinates of landmarks (biologically homologous), among several individuals, which are projected in a common tangent space where the different shape variables are extracted (Bookstein 1991). These variables are used to perform statistical analysis and to determine the spatial representation of the shape and its variation. Digital images of the ventral view of the specimens were taken with a digital camera, Canon Power Shot A620 7.1×. On each image, 10 landmarks were established (see Fig. 2) using the tpsDig 2.12 software (Rohlf 2008). Subsequently, landmarks were transformed into $x-y$ coordinates which were used to perform the statistical analysis. Additionally, we estimated individual centroid size and population consensus configuration to be used as a measure of linear covariation and av- 
erage population configuration, respectively, in the tpsSmall software (Rohlf 2003). Generalized Procrustes Analysis (GPA) was used to remove the variation not attributable to form (i.e. translation, rotation, and scale effects, Rohlf 1999). The relative warps (shape variables analogous to principal components) were obtained using tpsRelw software (Rohlf 2008). The first relative warp (RW1) explained the most of total variance (see Results); therefore this RW was used to show the morphological variation of the snails within and between biogeographic areas. Since there was no correlation between RW1 and centroid size, we performed a nested ANOVA on the RW1 to compare the shell variation between biogeographic areas and between locations, using 'area' as the fixed factor and 'location' as the random factor nested in area. Tukey's HSD tests were used for a posteriori comparisons (Zar 1999). To evaluate for potential correlation between genetic diversity and morphological variation in A. monodon across locations we conducted a Pearson's correlation test using the $H_{\mathrm{e}}$ per location as the genetic variable and the standard deviation of the RW1 per location as a morphological variable. These analyses were run in the Statistica v7.0 software (StatSoft).

\section{RESULTS}

\section{Statistic analysis of sequences}

A total of $605 \mathrm{bp}$ of the COI gene were analyzed in 258 individuals from 9 locations along the SEP coast. We found a total of 52 polymorphic sites (a total of 56 substitutions) and 46 haplotypes. High variation in the $H_{\mathrm{e}}$ between locations was observed, ranging from 0 for
Punta Arenas to 0.78 for Concepción, with an overall mean $( \pm \mathrm{SD})$ of $0.53 \pm 0.27$ (Table 1$)$ for the whole dataset. Although there was no detectable association between latitude and mitochondrial diversity (Spearman's rank correlation: $\mathrm{r}_{\mathrm{S}}=-0.075, t_{7}=-0.20, \mathrm{p}=0.85$ ), the COI gene was generally less diverse at the peripheral compared to the central locations (Table 1). Only 1 and 2 haplotypes were observed in the most southern and northern locations, respectively (Table 1). Genetic diversity was not significantly different across the 3 biogeographic areas (Kruskal-Wallis test $=0.78, \mathrm{df}=2$, $\mathrm{n}=9, \mathrm{p}=0.68)$. Nucleotide diversity was low in the whole data set, suggesting a low level of molecular differentiation (Table 1).

All $F_{\mathrm{ST}}$ pairwise comparisons between locations were significant $(p<0.05)$ with the lowest genetic differentiation observed within the IA, and the highest values recorded between locations from different biogeographic areas (Table 2). The AMOVA revealed significant genetic differences between the 3 biogeographic areas $\left(F_{\mathrm{CT}}=0.53 \mathrm{p}=0.005\right)$; and the SAMOVA analysis detected 4 different groups (Table 3). Additionally, although the Mantel test was significant $\left(\mathrm{R}^{2}=\right.$ $0.55, \mathrm{p}=0.001$ ), we detected 2 main groups, suggesting the influence of historical barriers to gene flow between populations of Acanthina monodon.

The haplotype network exhibited a complex pattern in the spatial distribution of the genetic lineages of Acanthina monodon (Fig. 1A). Three main clades could be recognized. Clade I was composed of unique haplotypes from the PP (north of $30^{\circ} \mathrm{S}$ ) with no shared haplotypes between the 2 locations sampled in this area (blue circles, Fig. 1A). Clade II was composed of a combination of shared haplotypes between the IA and MP and located

Table 1. Mitochondrial (COI gene) diversity by location and biogeographic area of the South-Eastern Pacific coast. PP: Peruvian Province; IA: Intermediate Area; MP: Magellan Province. $N_{\text {hap }}$ : number of haplotypes; $S$ : number of polymorphic sites; $H_{\mathrm{e}}$ : genetic diversity; $\pi_{1}$ : mean number of pairwise differences; $\pi_{2}$ : nucleotide diversity. Standard deviations are in parentheses

\begin{tabular}{|c|c|c|c|c|c|c|c|c|}
\hline Area & Location & Coordinates & $\mathrm{n}$ & $N_{\text {hap }}$ & $S$ & $H_{\mathrm{e}}$ & $\pi_{1}$ & $\pi_{2}$ \\
\hline \multirow[t]{2}{*}{ PP } & 1. Huasco & $28^{\circ} 24^{\prime} \mathrm{S}, 71^{\circ} 11^{\prime} \mathrm{N}$ & 29 & 2 & 1 & $0.25(0.09)$ & $0.25(0.29)$ & $0.000(0.000)$ \\
\hline & 2. Totoralillo & $30^{\circ} 04^{\prime} \mathrm{S}, 71^{\circ} 22^{\prime} \mathrm{N}$ & 26 & 6 & 13 & $0.68(0.07)$ & $1.39(0.88)$ & $0.002(0.002)$ \\
\hline Overall & & & 56 & 9 & 14 & $0.73(0.04)$ & $1.86(1.08)$ & $0.003(0.002)$ \\
\hline Average & & & 28 & 4.5 & 7 & $0.47(0.30)$ & $0.82(0,81)$ & $0.001(0.001)$ \\
\hline \multirow[t]{4}{*}{ IA } & 3. Las Cruces & $33^{\circ} 29^{\prime} \mathrm{S}, 71^{\circ} 38^{\prime} \mathrm{N}$ & 30 & 11 & 10 & $0.67(0.09)$ & $1.35(0.86)$ & $0.002(0.002)$ \\
\hline & 4. Concepción & $36^{\circ} 48^{\prime} \mathrm{S}, 73^{\circ} 10^{\prime} \mathrm{N}$ & 27 & 9 & 11 & $0.78(0.07)$ & $1.83(1.09)$ & $0.003(0.002)$ \\
\hline & 5. Valdivia & $39^{\circ} 46^{\prime} \mathrm{S}, 73^{\circ} 23^{\prime} \mathrm{N}$ & 30 & 7 & 6 & $0.42(0.11)$ & $0.52(0.45)$ & $0.001(0.001)$ \\
\hline & 6. Seno Reloncavi & $41^{\circ} 40^{\prime} \mathrm{S}, 72^{\circ} 39^{\prime} \mathrm{N}$ & 30 & 8 & 7 & $0.75(0.07)$ & $0.99(0.69)$ & $0.002(0.001)$ \\
\hline Overall & & & 117 & 35 & 34 & $0.68(0.05)$ & $1.22(0.78)$ & $0.002(0.001)$ \\
\hline Average & & & 29.3 & 8.8 & 8.5 & $0.66(0.16)$ & $1.17(0.55)$ & $0.002(0.001)$ \\
\hline \multirow[t]{3}{*}{ MP } & 7. Isla Ovalada & $44^{\circ} 03^{\prime} \mathrm{S}, 73^{\circ} 43^{\prime} \mathrm{N}$ & 26 & 8 & 9 & $0.78(0.05)$ & $2.38(1.34)$ & $0.004(0.003)$ \\
\hline & 8. Canal Vicuña & $44^{\circ} 59^{\prime} \mathrm{S}, 74^{\circ} 01^{\prime} \mathrm{N}$ & 30 & 2 & 1 & $0.48(0.05)$ & $0.48(0.43)$ & $0.001(0.001)$ \\
\hline & 9. Punta Arenas & $52^{\circ} 59^{\prime} \mathrm{S}, 70^{\circ} 40^{\prime} \mathrm{N}$ & 30 & 1 & 0 & 0 & 0 & 0 \\
\hline Overall & & & 86 & 11 & 10 & $0.77(0.03)$ & $2.80(1.49)$ & $0.005(0.003)$ \\
\hline Average & & & 28.7 & 3.7 & 3.3 & $0.42(0.39)$ & $0.95(1.25)$ & $0.002(0.002)$ \\
\hline
\end{tabular}


Table 2. Population pairwise genetic differentiation, $F_{\mathrm{ST}}$ (below diagonal), and pairwise geographic distance $(\mathrm{km})$ (above diagonal). Locations are numbered $(1-9)$ as in Table 1. All $F_{\text {ST }}$ values were significant $(p<0.05)$

\begin{tabular}{|lccccccccc|}
\hline Location & 1 & 2 & 3 & 4 & 5 & 6 & 7 & 8 & 9 \\
\hline 1 Huasco & - & 186 & 566 & 950 & 1278 & 1476 & 1750 & 1857 & 2728 \\
2 Totoralillo & 0.80 & - & 379 & 764 & 1091 & 1291 & 1563 & 1670 & 2544 \\
3 Las Cruces & 0.88 & 0.83 & - & 392 & 714 & 910 & 1185 & 1293 & 2116 \\
4 Concepción & 0.85 & 0.80 & 0.07 & - & 330 & 541 & 805 & 914 & 1808 \\
5 Valdivia & 0.94 & 0.89 & 0.08 & 0.09 & - & 219 & 473 & 580 & 1484 \\
6 S. Reloncaví & 0.91 & 0.85 & 0.04 & 0.07 & 0.04 & - & 278 & 384 & 1266 \\
7 Isla Ovalada & 0.84 & 0.78 & 0.21 & 0.20 & 0.22 & 0.21 & - & 107 & 1015 \\
8 Canal Vicuña & 0.94 & 0.89 & 0.19 & 0.18 & 0.21 & 0.18 & 0.28 & - & 981 \\
9 Punta Arenas & 0.99 & 0.96 & 0.86 & 0.82 & 0.94 & 0.89 & 0.77 & 0.95 & - \\
\hline
\end{tabular}

Table 3. Analysis of molecular variance (AMOVA) to test for the 3 biogeographic areas of the South-Eastern Pacific Coast and spatial analysis of molecular variance (SAMOVA) for 2, 3, 4 and 5 groups of locations (locations numbered 1-9 as in Table 1). Grouping showing the highest values for $F_{\mathrm{CT}}$ is in bold. See 'Genetic analysis' for definition of $F_{\mathrm{SC}}$ and $F_{\mathrm{CT}}$

\begin{tabular}{|c|c|c|c|}
\hline $\begin{array}{l}\text { No. of } \\
\text { groups }\end{array}$ & $\begin{array}{l}\text { Structure } \\
\text { tested }\end{array}$ & F-statistic & $\mathrm{p}$ \\
\hline 3 & $\begin{array}{l}\text { AMOVA } \\
(1-2)(3-4-5-6)(7-8-9)\end{array}$ & $\begin{array}{l}F_{\mathrm{SC}}=0.57 \\
F_{\mathrm{ST}}=0.80 \\
F_{\mathrm{CT}}=0.53\end{array}$ & $\begin{array}{c}<0.001 \\
<0.001 \\
0.005\end{array}$ \\
\hline 2 & $\begin{array}{l}\text { SAMOVA } \\
(1-2)(3-4-5-6-7-8-9)\end{array}$ & $\begin{array}{l}F_{\mathrm{SC}}=0.59 \\
F_{\mathrm{ST}}=0.86 \\
F_{\mathrm{CT}}=0.65\end{array}$ & $\begin{array}{c}<0.001 \\
<0.001 \\
0.024\end{array}$ \\
\hline 3 & $(1-2)(3-4-5-6-7-8)(9)$ & $\begin{array}{l}F_{\mathrm{SC}}=0.35 \\
F_{\mathrm{ST}}=0.84 \\
F_{\mathrm{CT}}=0.76\end{array}$ & $\begin{array}{c}<0.001 \\
<0.001 \\
0.005\end{array}$ \\
\hline 4 & (1) (2) $(3-4-5-6-7-8)(9)$ & $\begin{array}{l}F_{\mathrm{SC}}=0.19 \\
F_{\mathrm{ST}}=0.84 \\
F_{\mathrm{CT}}=\mathbf{0 . 8 1}\end{array}$ & $\begin{array}{c}<0.001 \\
<0.001 \\
0.010\end{array}$ \\
\hline 5 & (1) (2) (3-4-5-6-7) (8) (9) & $\begin{array}{l}F_{\mathrm{SC}}=0.11 \\
F_{S T}=0.82 \\
F_{\mathrm{CT}}=0.79\end{array}$ & $\begin{array}{c}<0.001 \\
<0.001 \\
0.010\end{array}$ \\
\hline
\end{tabular}

at the center of the network (red and green circles, Fig. 1A). Four mutational steps separated Clades I and II. Finally, Clade III was composed of a single haplotype from the most southerly location (location 9 in Table 1). Clades II and III were separated by 3 mutational steps. The most abundant haplotype (H1) was located in Clade II and was present in 6 of the 9 locations, with a relative frequency of $35 \%$ (4 localities from IA and 2 from MP). H1 had a central position on the network, so it could be an ancestral haplotype. From H1, several haplotypes arose separated by one mutational step, exhibiting the pattern of a star-like network (Fig. 1A).

The mismatch analysis was performed for Clades I and II and the whole data set (Fig. 1B-D). Clade III was left out of the analysis given the absence of diversity. Mismatch distribution in Clade I exhibited a multimodal pattern, suggesting that the species is in mutational-drift equilibrium and the data did not adjust to the expected model of expansion (Fig. 1B). The neutrality test revealed negative but non-significant Tajima and Fu's values $\left(D=-1.29, \mathrm{p}=0.08 ; F_{\mathrm{S}}=-1.24, \mathrm{p}=\right.$ 0.32). By contrast, Clade II exhibited negative and significant Tajima and Fu's values $\left(D=-2.35, \mathrm{p}<0.001 ; F_{\mathrm{S}}=\right.$ -28.16 ; $\mathrm{p}<0.001$ ) and a unimodal mismatch distribution pattern characteristic of populations under a sudden expansion dynamics (Fig. 1C). Mismatch distribution of the whole data set exhibited a multimodal pattern (Fig. 1D) with significant Tajima and Fu's values $(D=-1.59, \mathrm{p}=0.02$; $\left.F_{\mathrm{S}}=-25.20, \mathrm{p}<0.001\right)$.

\section{Morphometric analysis}

The morphological analysis of Acanthina monodon shells indicated a high degree of variability in shape, with most variation related to spire length (sum of squares $=0.192$ over landmarks 9 and 10) and to the thickness (sum of squares $=0.36$ over landmarks 6 and 7) of the shells (Fig. 2). In addition, the relative warp analysis indicated that these same landmarks were the most important in RW1 (eigenvector landmark $10=$ 78.41 on the $x$-coordinate and -95.70 on the $y$-coordinate), exhibiting a spatial separation across the latitude determined by spire length (Fig. 3). The morphological variation of the shell exhibited significant differences between locations (ANOVA, $F_{6,265}=96.87$, $\mathrm{p}<0.001$ ) but did not show a pattern of concordance with the biogeographical areas (nested ANOVA, $F_{2,6}=$ 3.94, $\mathrm{p}=0.081$ ). A significant change in RW1 was detected at 3 locations between 40 and $46^{\circ} \mathrm{S}$ (Tukey's HSD test, $\mathrm{p}<0.001$ ), indicating a southern group characterized by longer spires and thinner shells (Fig. 3). No correlation between mtDNA $H_{\mathrm{e}}$ and morphological variation was observed in A. monodon (Pearson's correlation: $\left.\mathrm{r}=-0.35, t_{7}=-1.00, \mathrm{p}=0.35\right)$.

\section{DISCUSSION}

The present study provides new insights into the potential role of biological and physical factors in explaining the variation in genetic structure and shell morphology of marine gastropod species on the SEP Coast. Genetic analyses of Acanthina monodon, a 

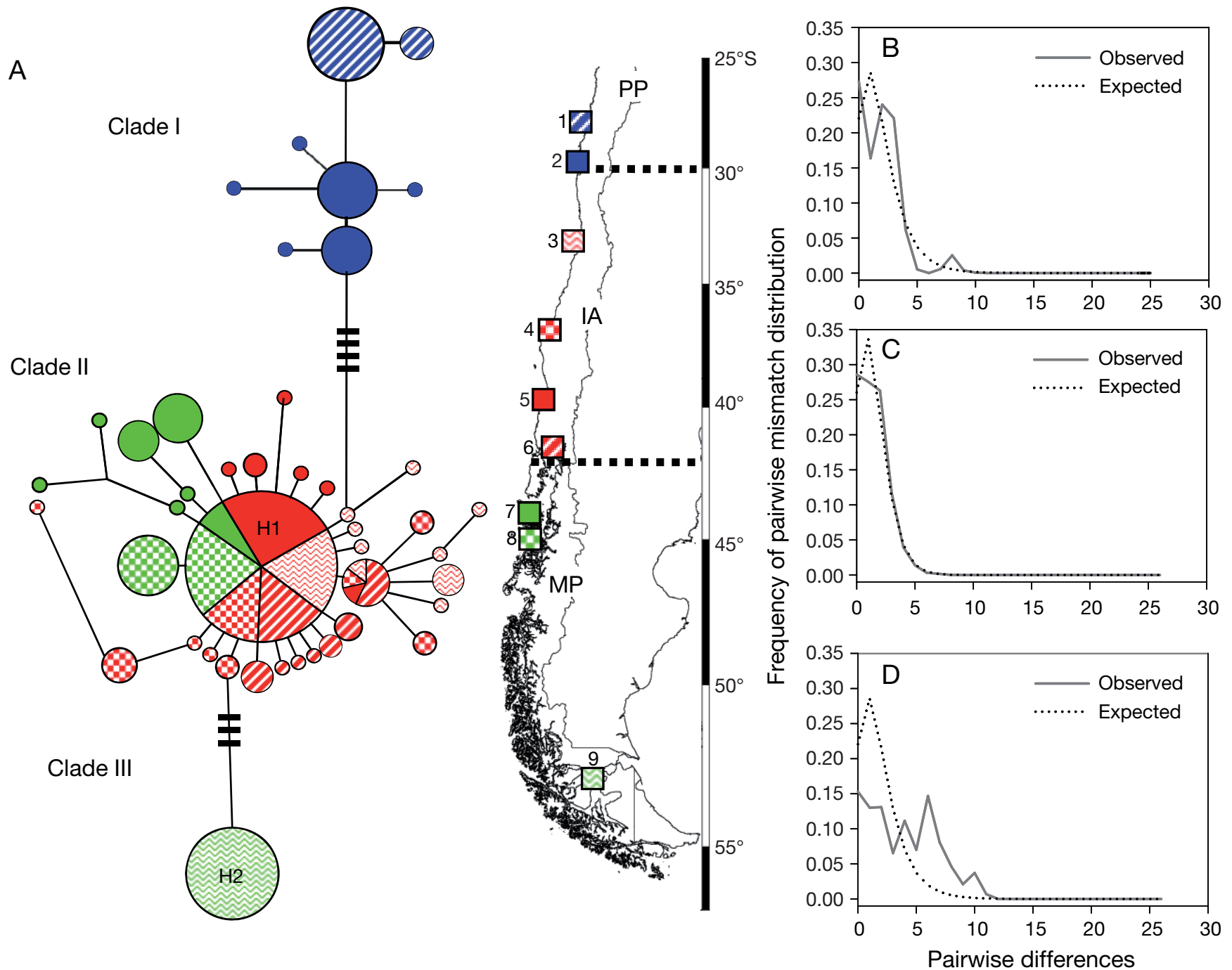

Fig. 1. Acanthina monodon. (A) Haplotype network of the 46 mtDNA haplotypes detected in 258 individuals from 9 different locations on the Chilean coast (indicated by squares on coastline map at center). Haplotype circle sizes are proportional to the number of individuals, and the distances between them are proportional to the mutational steps. Colours indicate the haplotype site (locations are numbered 1-9 as in Table 1). Blue, red and green colours correspond to the Peruvian Province (PP), Intermediate Area (IA) and Magellan Province (MP), respectively. Mismatch distributions are shown in (B) Clade I, (C) Clade II, and (D) the whole dataset

marine gastropod with low dispersal potential, indicated a moderate level of genetic diversity compared with other marine gastropods (examples in Kelly \& Palumbi 2010). There was spatial genetic structure that was not associated with biogeographic breaks at all and high variability of shell morphology, apparently affected by local environmental conditions.

Genetic diversity within locations decreased toward the boundaries of the distribution range of Acanthina monodon, whereas the genetic differentiation increased. This phenomenon is expected in peripheral populations, where at least 2 characteristics are considered important in defining the genetic diversity pattern. First, peripheral populations are generally frag- mented into patches in accordance with the patchiness of the environment (Brown et al. 1996), a feature that favours metapopulation processes (Holt \& Keitt 2000). Second, because marginal habitats are less suitable than those in the middle of the distribution range, the individual fitness and population growth rate will be lower at the periphery than in the centre of the distribution (Maurer \& Taper 2002). Thus, it is expected that peripheral populations will exhibit a reduced effective population size and higher genetic drift compared to those from the centre of the range. As result, population genetic diversity should decrease and genetic differentiation among populations should increase towards the periphery (e.g. Faugeron et al. 2004). In 


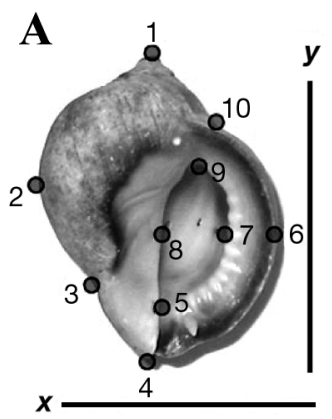

$\mathbf{B}$

1)

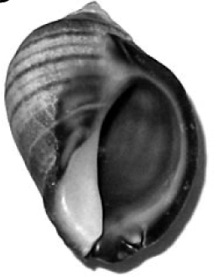

5)

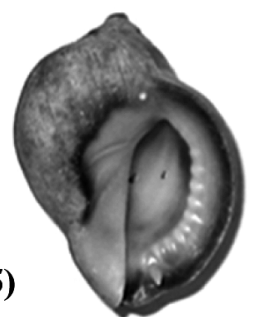

9)

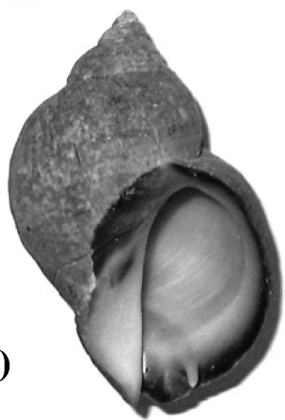

2)

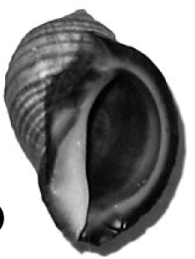

6)

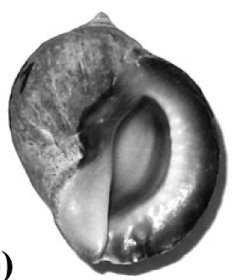

7)

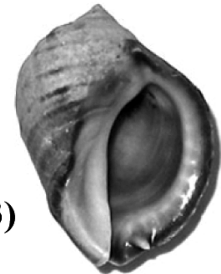

4)

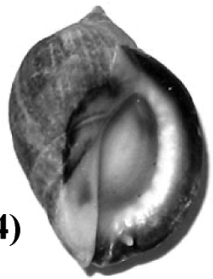

8)

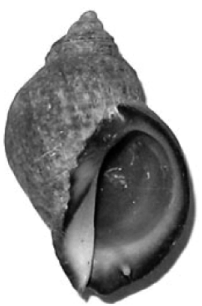

11)
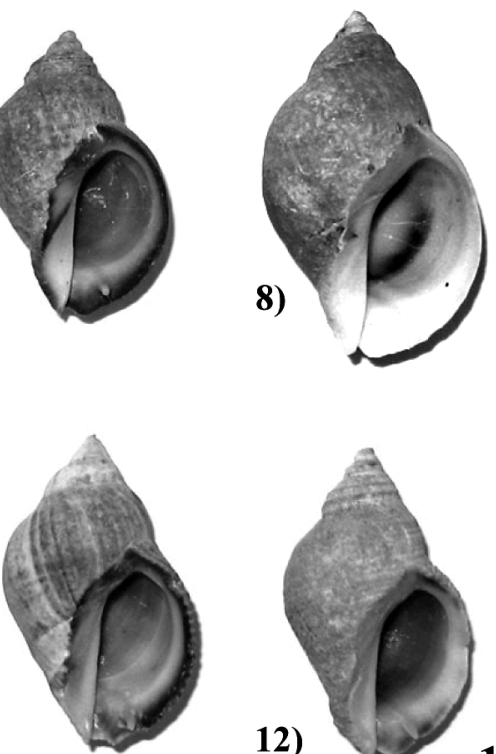

10)
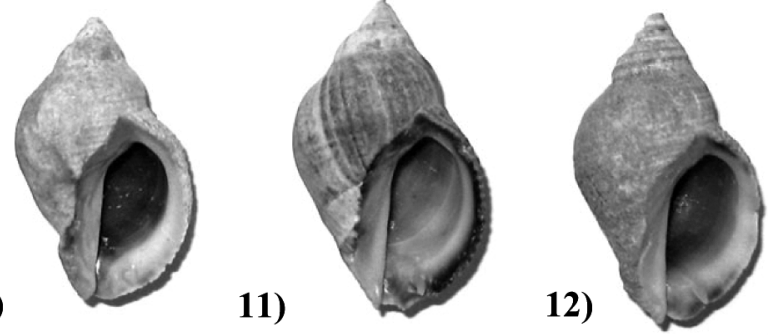

$1 \mathrm{~cm}$

Fig. 2. Acanthina monodon. (A) Ten morphological landmarks (from top left): (1) apex, (2) external largest volute, (3) end of the largest volute, (4) end of siphonal canal, (5) beginning of siphonal canal, (6) midpoint of the outer lip, (7) midpoint of the outer lip, (8) midpoint of the inner lip, (9) outer lip insertion, and (10) beginning of spire. (B) Morphotype of shells recorded for the 9 localities along the Chilean coast. Shells 1-3 from Concepción, 4-6 from Valdivia, 7-9 from Reloncaví, and 10-12 from Isla Ovalada

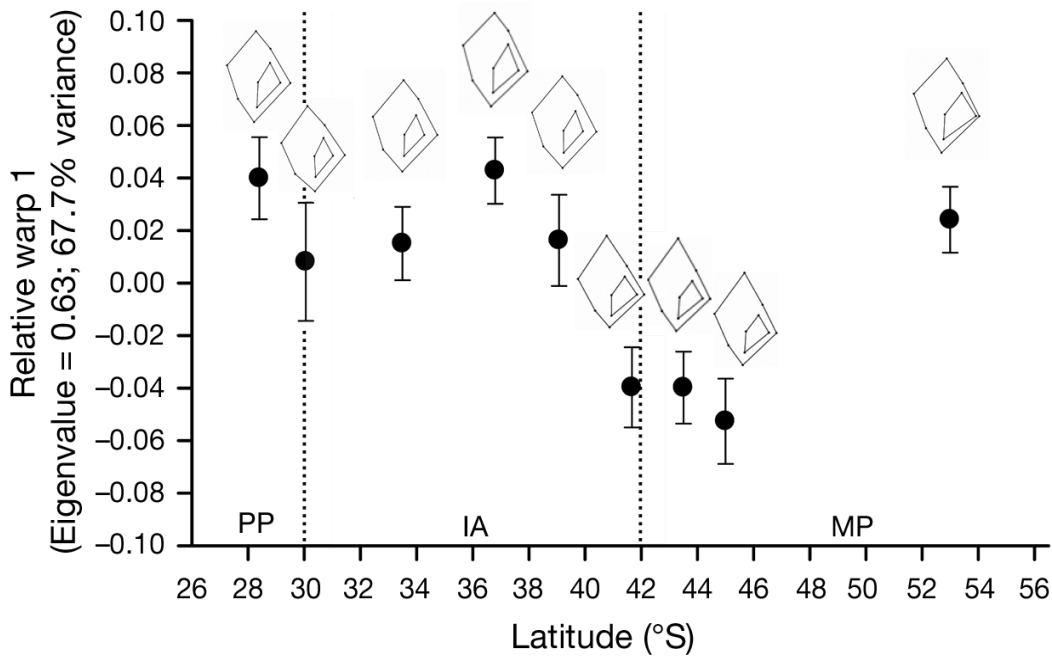

Fig. 3. Acanthina monodon. Mean $( \pm \mathrm{SD})$ latitudinal variation of relative warp 1 (shape variable) and consensus configuration by locality. Dotted lines denote boundaries between biogeographical areas: Peruvian Province (PP), Intermediate Area (IA) and Magellan Province (MP) addition, genetic differentiation among boundary populations may also arise by peripheral processes of local adaptation to these marginal environments (van Rossum et al. 1997). No data on fitness traits of $A$. monodon in its whole distribution range are available in literature. Field and experimental work are needed in order to test for a peripheral population effect in this species.

The 3 mitochondrial lineages we found were distributed in different geographic regions. The first linage occurred in the northern range of our study corresponding to the $\mathrm{PP}$; the second lineage occurs south of the $30^{\circ} \mathrm{S}$ biogeographic break and includes the IA and part of the MP populations; and the last composed only of individuals from the most southern location at the 
limit of distribution of Acanthina monodon. A number of mechanisms may interact to produce such a phylogeographic pattern. Here, a combination of the characteristic life cycle of $A$. monodon (direct development), the occurrence of mesoscale variation in oceanographic currents, and historical processes (e.g. glaciations) could be responsible for the present pattern as discussed below.

Since Acanthina mondon has direct development (Gallardo 1979), its low dispersal potential may explain the high genetic structure $\left(F_{S T}\right)$ and the significant positive correlation between genetic and spatial distance observed in this species. Several previous studies on marine species with limited dispersion from different taxonomic groups have found similar patterns (e.g. sea cucumbers: Arndt \& Smith 1998; fishes: Riginos \& Victor 2001, Dawson et al. 2002; barnacles: Sotka et al. 2004; gastropods: Kyle \& Boulding 2000, Collin 2001, Johnson \& Black 2006, Lee \& Boulding 2009; corals: Hellberg 1996, Miller \& Ayre 2008, Pelc et al. 2009; see also a meta-analysis by Kelly \& Palumbi 2010). Nevertheless, the 2 main groups observed in the isolation by distance analysis and the significant grouping pattern detected in the AMOVA and SAMOVA revealed a mesoscale (between region) genetic subdivision, suggesting that factors other than the characteristic life cycle of A. monodon may explain its phylogeographic pattern. Moreover, the SAMOVA presented a different regional grouping than that proposed by Camus (2001); it showed that the peripheral locations were very different from those at the centre of the range (grouping fourth in Table 3). Recent work emphasizes the role of environmental conditions, selection and historical events in explaining present-day population genetic structure (Miller \& Ayre 2008, Weersing \& Toonen 2009).

Concordance between patterns of phylogeography and biogeography has been observed in species of different taxa in many geographic areas, suggesting that factors similar to those that determine species distribution are moulding the spatial population genetic structure (Burton 1998, Avise 2000, Collin 2001, Hellberg et al. 2001, Barber et al. 2002, Jolly et al. 2005, Taylor \& Hellberg 2006). Recent studies focused on the major biogeographic breaks of the SEP coast indicate that the occurrence of this concordance appears to depend on the dispersal potential of the species. The kelp Lessonia nigrescens and the intertidal barnacle Notochthamalus scabrosus show an exact match between the genetic and biogeographic breaks at $30^{\circ} \mathrm{S}$ (Tellier et al. 2009, Zakas et al. 2009). In contrast, population genetic structures of the marine gastropod Concholepas concholepas, the barnacle Jehlius cirratus and the giant kelp Macrocystis pyrifera do not appear to match the $30^{\circ} \mathrm{S}$ biogeographic break (Cárdenas et al. 2009,
Zakas et al. 2009, Macaya \& Zuccarello 2010). For Acanthina monodon, a concordance between biogeographic and genetic breaks was observed at $30^{\circ} \mathrm{S}$. This biogeographic break is related to changes in oceanographic conditions, such as the shift in upwelling regimes that may have profound effects on the distribution and local dynamics of coastal marine populations and entire communities (Navarrete et al. 2008). This shift in oceanographic conditions may also be limiting gene flow between populations around $30^{\circ} \mathrm{S}$ in $\mathrm{A}$. monodon, L. nigrescens, and $N$. scabrosus. Similar effects have been reported for Cape Blanco in Oregon (Connolly et al. 2001) and the Cook Strait in New Zealand (Apte \& Gardner 2002). In these areas, which are influenced by similar upwelling regimes, the current flow appears to reduce the effective dispersal of marine invertebrate species (Sotka et al. 2004, Waters \& Roy 2004).

Physical and historical differences determine a clear break in species diversity at $42^{\circ} \mathrm{S}$ (Camus 2001, Valdovinos et al. 2003). However, at present there is less evidence supporting a population genetic break at this latitude in marine invertebrate species. The only previous broad-scale study carried out in this area on a marine gastropod found no evidence of a phylogeographic break in Concholepas concholepas (Cárdenas et al. 2009). Similarly, for Acanthina monodon, we did not observe a genetic break around $42^{\circ} \mathrm{S}$, although this species has a more restricted dispersal potential than C. concholepas. Nevertheless, the genetic differences observed between Clade II and III suggest the existence of a population genetic break between 45 and $53^{\circ} \mathrm{S}$. Previously, the occurrence of a faunistic break at around $48^{\circ} \mathrm{S}$ was suggested for benthic marine invertebrates inhabiting areas from the intertidal to 100 m (Lancellotti \& Vásquez 2009). However, in the present study, the lack of samples from this area did not allow us to identify the exact location of the genetic break in A. monodon. A more exhaustive sampling of this area is needed to resolve the existence of a population genetic break and to determine the potential causes of the lack of phylogeographic and biogeographic concordance.

The third clade distinguished in Acanthina monodon at the most southern locality sampled (Punta Arenas; $53^{\circ} \mathrm{S}$ ), which had only one private (i.e. only present in one location) haplotype (H2), may be the result of past glaciation processes reported for this area. Genetic evidence of postglacial recolonization in this area has recently been documented in the kelps Durvilleae antarctica (Fraser et al. 2010) and Macrocystis pyrifera (Macaya \& Zuccarello 2010) and also in a variety of Patagonian freshwater taxa (Cussac et al. 2004, Zemlak et al. 2008). For A. monodon the observations of genetic isolation, absence of genetic diversity in the 
most southerly location, and the star-like haplotype network observed in Clade II (Fig. 1) suggest a postglacial recolonization towards the south of $42^{\circ} \mathrm{S}$. In contrast to $A$. monodon, no evidence of postglacial recolonization was observed in Concholepas concholepas (Cárdenas et al. 2009). This result may be explained by the fact that $C$. concholepas inhabits intertidal and subtidal habitats (40 $\mathrm{m}$ depth; Moreno et al. 1993) enabling deeper populations to survive the advance of the ice sheet. By contrast, A. monodon is more restricted to the intertidal and thus was more likely to have been completely removed by the ice sheet during the last glacial maximum.

Interestingly, the shell morphology of Acanthina monodon exhibited a high level of variation at the small and macro spatial scales. Shell morphology varied significantly among locations within and between biogeographic areas south and north of $42^{\circ} \mathrm{S}$. Morphometric analysis indicated a change between 42 and $46^{\circ} \mathrm{S}$ toward individuals showing thinner shells and longer spires. These changes are coincident with a change in the coastal topography, wave exposure, and hydrology of this area. Reid \& Osorio (2000) suggested that these morphological differences may be associated with levels of wave exposure. Similarly, the reversion of shell morphology observed at Punta Arenas $\left(53^{\circ} \mathrm{S}\right.$; thicker shells) may be explained by a greater wave exposure condition observed in this locality with respect to the former area. However, other factors may affect shell morphology; Vermeij (1974) suggested that differences in the length of the spire could be related to the strength of predation pressure. It is not clear if the spatial variation in the shell morphology of A. monodon is attributable to biological or physical factors, or both, however differences in wave strength characteristics of different areas may be one of the main factors to explain this pattern. It appears that macro-scale morphological patterns are related to biogeographic patterns overlaid by local and idiosyncratic variation. Experimental studies are needed to evaluate the role of ecological and oceanographic factors and to elucidate regional and local process operating on shell morphology.

The absence of a correlation between $H_{\mathrm{e}}$ and morphological variability may be the result of the lack of association of the COI gene with the expression of shell morphology in Acanthina monodon. For example, in Nucella lapillus no significant molecular differentiation was observed between 2 morphological ecotypes for mtDNA, but a significant genetic structure at 2 microsatellite loci did suggest that the nuclear gene may be determining morphological patterns (GuerraVarela et al. 2009). In addition, in the genus Littorina, high heritabilities of shell morphology have been recorded, suggesting the participation of quantitative genes in the expression of this trait (Boulding \& Hay 1993, Johannesson \& Johannesson 1996, Carballo et al. 2001, Conde-Padín et al. 2007). Our results on the morphological variation of the A. monodon shell and its potential role in adaptive processes highlight the need for further research investigating local adaptation and heritability in this trait. Finally, the high morphological variation detected in A. monodon in this study did not support the use of shell morphology as a taxonomic trait in marine gastropods, and our results suggest, in contrast to other previous studies (DeVries 2003), that only one Acanthina species resides along the SEP coast.

Acknowledgements. We thank D. Gomez and G. Fuenzalida for their assistance on this project. This study was funded by FONDECYT (Fondo Nacional de Desarrollo Científico y Tecnológico) Grant No.11080068 and IFS (International Foundation for Science) A/4608-1 to LC.

\section{LITERATURE CITED}

Apte S, Gardner JPA (2002) Population genetic subdivision in the New Zealand greenshell mussel (Perna canaliculus) inferred from single-strand conformation polymorphism analysis of mitochondrial DNA. Mol Ecol 11:1617-1628

Arndt A, Smith MJ (1998) Genetic diversity and population structure in two species of sea cucumber: differing patterns according to mode of development. Mol Ecol 7:1053-1064

Avise JC (2000) Phylogeography: the history and formation of species. Harvard University Press, Cambridge, MA

Avise JC, Arnold J, Ball RM, Bermingham E and others (1987) Intraspecific phylogeography: the mitochondrial DNA bridge between population genetics and systematics. Annu Rev Ecol Syst 18:489-522

> Bandelt HJ, Forster P, Röhl A (1999) Median-joining networks for inferring intraspecific phylogenies. Mol Biol Evol 16: $37-48$

Barber PH, Palumbi SR, Erdmann MV, Moosa MK (2002) Sharp genetic breaks among populations of Haptosquilla pulchella (Stomatopoda) indicate limits to larval transport: patterns, causes, and consequences. Mol Ecol 11:659-674

Bookstein FL (1991) Morphometric tools for landmark data: geometry and biology. Cambridge University Press, New York, NY

Boulding E, Hay T (1993) Quantitative genetics of shell form of an intertidal snail: constraints on shortterm response to selection. Evolution 47:576-592

Broitman BR, Navarrete SA, Smith F, Gaines SD (2001) Geographic variation of southeastern Pacific intertidal communities. Mar Ecol Prog Ser 224:21-34

> Brown JH, Stevens GC, Kaufman DM (1996) The geographic range: size, shape, boundaries, and internal structure. Annu Rev Ecol Syst 27:597-623

Burton RS (1998) Intraspecific phylogeography across the Point Conception biogeographic boundary. Evolution 52: 734-745

> Camus PA (2001) Biogeográfia marina de Chile continental. Rev Chil Hist Nat 74:587-617

Carballo M, Garcia C, Rolán-Alvarez E (2001) Heritability of shell traits in wild Littorina saxatilis populations: results across a hybrid zone. J Shellfish Res 20:415-422 
Cárdenas L, Castilla JC, Viard F (2009) A phylogeographical analysis across three biogeographical provinces of the south-eastern Pacific: the case of the marine gastropod Concholepas concholepas. J Biogeogr 36:969-981

> Chavez FP, Ryan J, Lluch-Cota SE, Niquen M (2003) From anchovies to sardines and back: multidecadal change in the Pacific Ocean. Science 299:217-221

Collin R (2001) The effects of mode of development on phylogeography and population structure of North Atlantic Crepidula (Gastropoda: Calyptraeidae). Mol Ecol 10: $2249-2262$

> Conde-Padín P, Carvajal-Rodríguez A, Carballo M, Caballero A, Rolán-Alvarez E (2007) Genetic variation for shell traits in a direct-developing marine snail involved in a putative sympatric ecological speciation process. Evol Ecol 21: 635-650

Connolly SR, Menge BA, Roughgarden J (2001) A latitudinal gradient in recruitment of intertidal invertebrates in the northeast Pacific Ocean. Ecology 82:1799-1813

Cox CB, Moore PD (2000) Biogeography; an ecological and evolutionary approach, 6th edn. Blackwell Science, Oxford

> Cussac V, Ortubay S, Iglesias G, Milano D and others (2004) The distribution of South American galaxiid fishes: the role of biological traits and post-glacial history. J Biogeogr 31:103-121

> Dawson MN, Louie KD, Barlow M, Jacobs DK, Swift CC (2002) Comparative phylogeography of sympatric sister species, Clevelandia ios and Eucyclogobius newberryi (Teleostei, Gobiidae), across the California Transition Zone. Mol Ecol 11:1065-1075

DeVries TJ (2003) Acanthina Fischer von Waldheim, 1807 (Gastropoda: Muricidae), an ocenebrine genus endemic to South America. Veliger 46:332-350

> Dupanloup I, Schneider S, Excooffier L (2002) A simulated annealing approach to define the genetic structure of populations. Mol Ecol 11:2571-2581

Excoffier L, Smouse PE, Quattro JM (1992) Analysis of molecular variance inferred from metric distances among DNA haplotypes: application to human mitochondrial DNA restriction data. Genetics 131:479-491

Excoffier L, Laval G, Schneider S (2005) Arlequin (version 3.0): an integrated software package for population genetics data analysis. Evol Bioinform Online 1:47-50

Faugeron S, Martinez EA, Correa JA, Cárdenas L, Destombe C, Valero M (2004) Reduced genetic diversity and increased population differentiation in peripheral and overharvested populations of Gigartina skottsbergii (Rhodophyta, Gigartinales) in southern Chile. J Phycol 40: 454-462

Filatov DA (2002) Proseq: software for preparation and evolutionary analysis of DNA sequence datasets. Mol Ecol Notes 2:621-624

Folmer O, Black M, Hoeh W, Lutz R, Vrijenhoek R (1994) DNA primers for amplification of mitochondrial cytochrome c oxidase subunit I from diverse metazoan invertebrates. Mol Mar Biol Biotechnol 3:294-299

> Fraser CI, Thiel M, Spencer H, Waters J (2010) Contemporary habitat discontinuity and historic glacial ice drive genetic divergence in Chilean kelp. BMC Evol Biol 10:203

Fu YX (1997) Statistical tests of neutrality of mutations against population growth, hitchhiking and background selection. Genetics 147:915-925

Gallardo CS (1979) Developmental pattern and adaptations for reproduction in Nucella crassilabrum and other muricacean gastropods. Biol Bull (Woods Hole) 157:453-463

> Guerra-Varela J, Colson I, Backeljau T, Breugelmans K, Hughes RN, Rólan-Alvarez E (2009) The evolutionary mechanism maintaining shell shape and molecular differentiation between two ecotypes of the dogwhelk Nucella lapillus. Evol Ecol 23:261-280

> Hellberg ME (1996) Dependence of gene flow on geographic distance in two solitary corals with different larval dispersal capabilities. Evolution 50:1167-1175

> Hellberg ME, Balch DP, Roy K (2001) Climate-driven range expansion and morphological evolution in a marine gastropod. Science 292:1707-1710

Holt RD, Keitt TH (2000) Alternative causes for range limits: a metapopulation perspective. Ecol Lett 3:41-47

Hormazabal S, Shaffer G, Leth O (2004) Coastal transition zone off Chile. J Geophys Res 109:C01021, doi:10.1029/ 2003JC001956

Hulton NRJ, Purves RS, McCulloch RD, Sugden DE, Bentley MJ (2002) The Last Glacial maximum and deglaciation in southern South America. Quat Sci Rev 21:233-241

Johannesson B, Johannesson K (1996) Population differences in behaviour and morphology in the snail Littorina saxatilis: phenotypic plasticity or genetic differentiation. J Zool 240:475-493

> Johnson MS, Black R (2006) Effects of mode of reproduction on genetic divergence over large spatial and temporal scales in intertidal snails of the genus Bembicium Philippi (Gastropoda: Littorinidae). Biol J Linn Soc 89:689-704

Jolly MT, Jollivet D, Gentil F, Thiébaut E, Viard F (2005) Sharp genetic break between Atlantic and English Channel populations of the polychaete Pectinaria koreni, along the north coast of France. Heredity 94:23-32

Kelly RP, Eernisse DJ (2007) Southern hospitality: a latitudinal gradient in gene flow in the marine environment. Evolution 61:700-707

Kelly RP, Palumbi SR (2010) Genetic structure among 50 species of the northeastern Pacific rocky intertidal community. PLoS ONE 5:e8594

Kyle CJ, Boulding EG (2000) Comparative population genetic structure of marine gastropods (Littorina spp.) with and without pelagic larval dispersal. Mar Biol 137:835-845

> Lancellotti DA, Vásquez JA (1999) Biogeographical patterns of benthic macroinvertebrates in the Southeastern Pacific littoral. J Biogeogr 26:1001-1006

Lee HJ, Boulding EG (2009) Spatial and temporal population genetic structure of four northeastern Pacific littorinid gastropods: the effect of mode of larval development on variation at one mitochondrial and two nuclear DNA markers. Mol Ecol 18:2165-2184

Macaya EC, Zuccarello GC (2010) Genetic structure of the giant kelp Macrocystis Pyrifera along the southeastern Pacific. Mar Ecol Prog Ser 420:103-112

> Maurer BA, Taper ML (2002) Connecting geographical distributions with populations processes. Ecol Lett 5:223-231

McPhaden MJ (1999) Genesis and evolution of the 1997-98 El Niño. Science 283:950-954

> Miller KJ, Ayre DJ (2008) Protection of genetic diversity and maintenance of connectivity among reef corals within marine protected areas. Conserv Biol 22:1245-1254

Moreno CA, Asencio G, Ibañez S (1993) Patrones de asentamiento de Concholepas concholepas (Bruguière) (Mollusca: Muricidae) en la zona intermareal rocosa de Valdivia, Chile. Rev Chil Hist Nat 66:93-101

> Navarrete SA, Broitman BR, Menge BA (2008) Interhemispheric comparison of recruitment to intertidal communities: pattern persistence and scales of variation. Ecology 89:1308-1322

> Pelc RA, Warner RR, Gaines SD (2009) Geographical patterns of genetic structure in marine species with contrasting life histories. J Biogeogr 36:1881-1890 
Polzin T, Daneshmand SV (2003) On Steiner trees and minimum spanning trees in hypergraphs. Oper Res Lett 31: $12-20$

Ragionieri L, Fratini S, Vannini M, Schubart CD (2009) Phylogenetic and morphometric differentiation reveal geographic radiation and pseudo-cryptic speciation in a mangrove crab from the Indo-West Pacific. Mol Phy Evol 52:825-834

Reid DG, Osorio C (2000) The shallow-water marine Mollusca of the Estero Elefantes and Laguna San Rafael, southern Chile. Bull Nat Hist Mus Lond (Zool) 66:109-146

Riginos C, Victor BC (2001) Larval spatial distributions and other early life-history characteristics predict genetic differentiation in eastern Pacific blennioid fishes. Proc Biol Sci 268:1931-1936

Rivadeneira MM, Fernández M, Navarrete SA (2002) Latitudinal trends of species diversity in rocky intertidal herbivore assemblages: spatial scale and the relationship between local and regional species richness. Mar Ecol Prog Ser 245:123-131

Rohlf FJ (1999) Shape statistics: Procrustes superimpositions and tangent spaces. J Classif 16:197-223

Rohlf FJ (2003) tpsSmall 1.20. Computer Program. SUNY, Stony Brook, NY

Rohlf FJ (2008) tpsRelw 1.46. Computer Program. SUNY, Stony Brook, NY

Sambrook J, Fritsch EF, Maniatis T (1989) Molecular cloning: a laboratory manual. Cold Spring Harbor Laboratory Press, Cold Spring Harbor, NY

Sanford E, Roth MS, Johns GC, Wares JP, Somero GN (2003) Local selection and latitudinal variation in a marine predator-prey interaction. Science 300:1135-1137

Slatkin M, Hudson RR (1991) Pairwise comparisons of mitochondrial DNA sequences in stable and exponentially growing populations. Genetics 129:555-562

Sotka EE, Wares JP, Barth JA, Grosberg RK, Palumbi SR (2004) Strong genetic clines and geographical variation in gene flow in the rocky intertidal barnacle Balanus glandula. Mol Ecol 13:2143-2156

Strub PT, Mesias JM, Montecino V, Rutllant J, Salinas S (1998) Coastal ocean circulation off western South America. In: Robinson AR, Brink KH (eds) The Sea. Wiley \& Sons, New York, NY, p 11:273-313

Tajima F (1989) Statistical method for testing the neutral mutation hypothesis by DNA polymorphism. Genetics 23:585-595

Taylor MS, Hellberg ME (2006) Comparative phylogeography of a genus of coral reef fishes: biogeographical and genetical concordance in the Caribbean. Mol Ecol 15: 695-707

Tellier F, Meynard AP, Correa JA, Faugeron S, Valero M (2009) Phylogeographic analyses of the $30^{\circ} \mathrm{S}$ south-east Pacific biogeographic transition zone establish the occurrence of a sharp genetic discontinuity in the kelp Lessonia nigrescens: Vicariance or parapatry? Mol Phylogenet Evol $53: 679-693 \mathrm{v}$

Thiel M, Macaya EC, Acuna E, Arntz WE and others (2007) The Humboldt Current System of northern and central Chile. Oceanogr Mar Biol Annu Rev 45:195-344

Thompson JD, Gibson TJ, Plewniak F, Jeanmougin F, Higgins DG (1997) The ClustalX windows interface: flexible strategies for multiple sequence alignment aided by quality analysis tools. Nucleic Acids Res 25:4876-4882

Trussell GC, Smith LD (2000) Induced defenses in response to an invading crab predator: an explanation of historical and geographic phenotypic change. Evolution 97: 2123-2127

Valdovinos CR (1999) Biodiversidad de moluscos chilenos: base de datos taxonómica y distribucional. Gayana Zool (Chile) 63:59-112

Valdovinos C, Navarrete SA, Marquet PA (2003) Mollusk species diversity in the Southeastern Pacific: Why are there more species towards the pole? Ecography 26:139-144

van Rossum F, Vekemans X, Meerts P, Gratia E, Lefebvre C (1997) Allozyme variation in relation to ecotypic differentiation and population size in marginal populations of Silene nutans. Heredity 78:552-560

Vermeij GJ (1974) Marine faunal dominance and moluscan shell form. Evolution 28:656-664

> Waters JM, Roy MS (2004) Phylogeography of a high-dispersal New Zealand sea-star: Does upwelling block geneflow? Mol Ecol 13:2797-2806

Weersing K, Toonen RJ (2009) Population genetics, larval dispersal, and connectivity in marine systems. Mar Ecol Prog Ser 393:1-12

Zakas C, Binford J, Navarrete SA, Wares JP (2009) Restricted gene flow in Chilean barnacles reflects an oceanographic and biogeographic transition zone. Mar Ecol Prog Ser 394:165-177

Zar JH (1999) Biostatistical analysis, 4th edn. Prentice Hall, Upper Saddle River, NJ

Zemlak TS, Habit EM, Walde SJ, Battini MA, Adams EDM, Ruzzante DE (2008) Across the southern Andes on fin: glacial refugia, drainage reversals and a secondary contact zone revealed by the phylogeographical signal of Galaxias platei in Patagonia. Mol Ecol 17:5049-5061

Submitted: November 26, 2010; Accepted: April 27, 2011

Proofs received from author(s): July 15, 2011
Editorial responsibility: Roger Hughes,

Bangor, UK 